\title{
Prospects for the use of herbal medicines in relation to progressing environmental pollution
}

\author{
Perspektywy zastosowania leków ziołowych w związku z postępującym \\ zanieczyszczeniem środowiska
}

\author{
Jarogniew J. Łuszczki ${ }^{1,2, A, D-F \oplus}$, Katarzyna Gustaw-Rothenberg ${ }^{3, E-F}{ }^{\oplus}$, Jarosław Chmielewski ${ }^{4, B-D, F} \oplus$, \\ Magdalena Florek-Łuszczki ${ }^{5, A, C-D, F \oplus}$ \\ ${ }^{1}$ Department of Pathophysiology, Medical University, Lublin, Poland \\ ${ }^{2}$ Isobolographic Analysis Laboratory, Institute of Rural Health, Lublin, Poland \\ ${ }^{3}$ Cleveland Clinic Lerner College of Medicine of Case Western Reserve University Neurological Institute: Lou Ruvo Center \\ for Brain Health, Departments of Psychiatry and Neurology as well as Huntingtonss disease Center of Excellence, United \\ States \\ ${ }^{4}$ Institute of Environmental Protection - National Research Institute in Warsaw, Poland \\ ${ }^{5}$ Department of Medical Anthropology, Institute of Rural Health, Lublin, Poland \\ A - Koncepcja i projekt badania, B - Gromadzenie i/lub zestawianie danych, C - Analiza i interpretacja danych, \\ D - Napisanie artykułu, E - Krytyczne zrecenzowanie artykułu, F - Zatwierdzenie ostatecznej wersji artykułu
}

Łuszczki JJ, Gustaw-Rothenberg K, Chmielewski J, Florek-Łuszczki M. Prospects for the use of herbal medicines in relation to progressing environmental pollution. Med Środ. 2019; 22(1-2): 5-8. doi: $10.26444 / \mathrm{ms} / 117884$

\begin{abstract}
Abstrakt
Due to the increasing pollution of the natural environment, the amount of impurities that can accumulate in herbs and plants used for therapeutic purposes as medicinal plants also increases. As many plant materials have medicinal properties and have been used as medicinal remedies,they must be subjected to rigorous assessments according to material quality standards.Presently, however, there is no guarantee that there has been no change in the amount and content of medicinal bioactive substances, compared to plants used years ago in traditional folk medicine. At present, there are great prospects in the use of medical plants, especially if the medicinal plants are free from pollution originating from the contaminated natural environment. The attention of researchers should focus not only on seeking new bioactive compounds and finding new drugs in plants, but also on ensuring high standards of quality regarding the evaluation of the chemical purity of plants growing in the environment exposed to contamination and pollution. The combination of both challenges can help patients suffering from increasing numbers of ailments and diseases of civilization. Researchers must also be actively involved in the process of detection any harmful substances penetrating from the environment into plants by applying various biomedical and chemical techniques to detect some novel, as yet unknown threats, in order not to expose patients to them.
\end{abstract}

\section{Key words}

pollution, environment, medicinal herbs, diseases of civilization, plant raw material

\section{Streszczenie}

Wraz z rosnącym zanieczyszczeniem środowiska naturalnego zwiększa się również ilość zanieczyszczeń, które mogą gromadzić się w ziołach i roślinach wykorzystywanych do celów terapeutycznych w miarę ich wzrostu. Aby materiały roślinne miały właściwości lecznicze i mogły być stosowane jako środki lecznicze, należy je poddać rygorystycznej ocenie zgodnie z normami jakości materiałów. Obecnie nie ma jednak żadnej gwarancji, że nie nastąpiła zmiana ilości i zawartości leczniczych substancji bioaktywnych w roślinach wykorzystywanych do celów terapeutycznych w porównaniu z roślinami stosowanymi przed laty w tradycyjnej medycynie ludowej. Możliwości medycznego wykorzystania roślin są szerokie, zwłaszcza jeśli rośliny lecznicze są wolne od zanieczyszczeń pochodzących z zanieczyszczonego środowiska naturalnego. Uwaga badaczy powinna koncentrować się nie tylko na poszukiwaniu nowych bioaktywnych związków i odkrywaniu nowych substancji leczniczych w roślinach, ale także na zapewnieniu wysokich standardów czystości chemicznej roślin rosnących w środowisku narażonym na skażenie i zanieczyszczenie. Połączenie obu wyzwań może pomóc pacjentom cierpiącym na coraz większą liczbę dolegliwości i chorób cywilizacyjnych. Naukowcy muszą również aktywnie uczestniczyć w procesie wykrywania wszelkich szkodliwych substancji przenikających ze środowiska do roślin, stosując różne techniki biomedyczne i chemiczne, aby wykryć nieznane dotąd zagrożenia i tym samym uchronić przed nimi pacjentów.

\section{Słowa kluczowe}

zanieczyszczenia, środowisko, choroby cywilizacyjne, rośliny medyczne, surowy materiał roślinny 


\section{INTRODUCTION}

The therapeutic use of herbs in medicine, in particular as decoctions, infusions, dry extracts, liquid extracts, tinctures and essential oils from medicinal plants, has been known to mankind for millennia $[1,2]$. It is widely accepted that folk medicine is based on herbs and medicines of plant origin. The ancient knowledge on the therapeutic properties of herbs and medicinal plants (phytotherapy) can be found in the works of Greek, Chinese, Egyptian or Ayurvedic medics [1].

Currently, great interest focuses on herbs, medicinal plants and their preparations, as a source of active compounds and substances which, after isolation, are used in the therapy of various human diseases [3]. Pharmacognosy specialists are looking for plants containing high concentrations of bio-active substances that can be used in the therapy of various human diseases and illnesses $[4,5]$. There is no doubt that plant materials are the best source for the production of medicines $[6,7]$.

On the other hand, many drugs currently used in Western medicine have been discovered and developed after isolation of some bio-active compounds from medicinal herbs and plants, which were first successfully used in folk medicine. For instance, the hypnotic and sedative effects of the opium poppy have long been known and used to relieve pain since antiquity [8], but experimental studies on the effects of the opium poppy on the mammalian brain led to the discovery of the endogenous endorphins and opioid system [9]. As a result, we have now morphine and other opioid analgesics as drugs which considerably alleviate pain and reduce pain sensation in humans $[10,11]$. A similar situation is related to marijuana, since its healing properties have been described in details in the work of ancient Chinese medics [12]. Currently, the therapeutic effects of marijuana have contributed to intensive research, the result of which is the discovery of the endogenous cannabinoid system in vertebrates $[13,14]$.

\section{STATE-OF-THE-ART KNOWLEDGE}

With the progress and development of civilization, our knowledge about the medicinal properties of plants used centuries ago in folk medicine increases. At the same time, the progress of civilization entails an increase in environmental pollution, the consequence of which is the degradation of plants and the development of human diseases called diseases of civilization $[15,16]$. Unfortunately, environmental contamination and pollution entail a decrease in the quality of the plant raw material, which can accumulate not only heavy metals and toxins, but also herbicides, pesticides, and other chemicals that enter plants with water and air [17]. The most frequent contaminants of medicinal plants are pesticide residues, heavy metals, mycotoxins, polycyclic aromatic hydrocarbons and pyrrolizidine alkaloids [18]. Pollution of the environment with heavy metals causes these metals to penetrate plants growing on contaminated soils $[19,20]$. The European Pharmacopeia sets limits for some popular heavy metals, including cadmium, lead, mercury, arsenic, cobalt, nickel, vanadium and thallium, which can be found in plant materials [21, 22]. No additional regulations need to be set for other heavy metals that can be detected in medicinal plants, including, aluminium, iron, copper and zinc [22].
Aflatoxins and mycotoxins produced by various strains of the fungus Aspergillus are considered harmful for people consuming medicinal plants [23, 24]. Microbial (bacterial) contamination of medicinal plants may be harmful for patients, unless the final products of herbal origin undergo ethanolic extraction or are used after contacting with boiled water [25]. Raw plant materials that can be used by the patients are usually exposed to high microbial load [26]. Another group of contaminants found in medicinal plants is polycyclic aromatic hydrocarbons (PAH), including, benzo(a) pyrene, benzo(a)anthracene, benzo(a)fluoroanthene and chrysene [27,28]. Medicinal plants are usually contaminated with pyrrolizidine alkaloids (PA), which are hepatotoxic and genotoxic with carcinogenic risks for human [29, 30].

To ensure the patients safety, all the limits of contaminants in the medicinal plants should not be exceeded. Analytical testing is required to ensure the purity of medicinal plants at any stage of production, from growing and cultivating the medicinal plants, collecting and harvesting the herbal materials, manufacturing and distributing the medicinal plants and medicinal drugs [17].

It is not possible to entirely eliminate contaminants from herbal medicinal plants (e.g. natural radionuclides, heavy metals, and chemical compounds) because they exist naturally in soil, air, and water as environmental contaminants. There is no doubt that high concentrations of these contaminants exist which pose a grave risk to health. On the other hand, some microbiological pathogens, including bacteria, mould and yeast, are also considered to be natural common contaminants of medicinal plants. Unfortunately, all these biologically active compounds may be harmful for patients in the case of their ingestion, especially in highly immunocompromised patients. Microbial pathogens can also be a main source of infections or intoxication with microbial metabolites.

The use of Cannabis sativa L. products under the name of' 'medical marijuana' continues to expand rapidly across the world. Along with increasing interest of Cannabis treatment by patients with difficult-to-treat diseases (including, epilepsy, glaucoma, cytotoxic chemotherapy in cancer patients, neuropathic pain, and AIDS-related cachexia) $[31,32]$, microbiological and toxicological safety becomes important issues for public health and environmental medicine. No doubt exists that the application of 'medical marijuana' by patients also requires that raw plant material and herbal products should be free of toxic compounds from a contaminated environment. For instance, evaluation of the purity of Cannabis sativa preparations revealed that the plant materials collected from 20 different dispensaries in USA were contaminated with various bacterial and fungal strains [33]. To ensure the biological purity of Cannabis sativa preparations, the utmost caution is advised during all processes of production and distribution of this medicinal plant material. The safe and standardized conditions of preparations of Cannabis sativa material should guarantee microbiological purity of 'medicinal marijuana'. Besides, some procedures allowing eliminating microbial pathogens should be implemented immediately in order not to expose immunosuppressed patients to the risk of danger to life.

On the other hand, the tendency of man to improve and select the most desired plant species and varieties may cause that the content of bioactive substances in plant materials may increase, or that these plants will become more susceptible to 
some diseases [34-37]. Thus, the pollution and degradation of the environment will automatically reflect on the pollution of plant raw materials from which herbal medicines are obtained. The selection of the appropriate plant varieties and the cultivation of special strains of plants can play an important role in the process of obtaining the best plant materials, as is the case with 'medical marijuana' $[7,34]$. Growers of' 'medical marijuana' select and cultivate only those strains of Cannabis sativa that have high content of cannabimimetic substances activating cannabinoid CB1 and $\mathrm{CB} 2$ receptors, with a small amount of psychoactive substances [38-40].

It is widely accepted that plants can be exposed to contamination with heavy metals by taking toxic compounds directly from soil, or when watering with contaminated water and/or rain containing dissolved pollution from the air [41, 42]. An increase in ionizing radiation (i.e., increased radiation at the sites of mining heaps) can trigger mutations in plants that impair their growth [43]. The question therefore arises whether the plant raw material and the drugs derived from it have the same composition and therapeutic properties as their counterparts used thousands or hundreds of years ago in folk medicine. This problem is very important because it applies not only to people living today, but also to the next generations in the future.

Additionally, the exposition of plants to various pesticides can contaminate the plant raw material causing, finally, the negative impact of phytotherapy on human health [18]. Although pesticides protect the plants from deleterious pests, they can also contribute negatively to the possibility of the application of medicinal materials in medicine [44-47]. Presently, European Pharmacopeia sets limits for approx. 70 various chemical compounds (pesticide residues) which continuously undergo updating and modifications. Some pesticide residue limits decrease (i.e. bromide), while other limits increase (i.e. pendimethaline) [48, 49]. High requirements concerning the purity of plant-derived materials allow us to maintain the content of bioactive substances on a desired high level that would be sufficient to produce therapeutic effects in patients who take the plant-derived medicines [50-53]. At present, to collect plant raw materials, we are obliged to cultivate the respective medicinal herbs and plants. In contrast, several decades or even hundred of years ago the plant raw materials were gathered as a result of collection of the plants by pickers. Presently, raw plant materials are transferred from special plantations to pharmaceutical companies which isolate and modify the raw materials, transforming them into drugs and herbal remedies. Since the source of plant materials could be contaminated due to progressing environmental pollution, plant raw materials have to be kept as pure as possible by following strict and rigorous rules and regulations $[54,55]$.

\section{CONCLUSIONS}

Environmental changes observed nowadays, (including increased pollution of water, soil and the air), rearrange the content of bioactive substances isolated from medicinal plants [56]. Therefore, to keep plant materials safe for humans and rich in bioactive compounds, researchers must follow strict and rigorous guidelines related with the detection of the chemical substances isolated from medicinal plants and herbs, and the selection of only those strains of herbs and medicinal plants which would offer the most favourable healthy effects for humans when used as plant remedies. Thus, the utmost caution is necessary to protect plant materials from contamination and pollution so as to be able to apply these plants as herbal remedies. There is no doubt that traditional (folk) medicine is still alive and phytotherapy with herbal remedies can offer some patients benefits related with the treatment of various human ailments and diseases of civilization with plant-derived drugs.

\section{REFERENCES}

1. Leonti M, Verpoorte R. Traditional Mediterranean and European herbal medicines. J Ethnopharmacol. 2017; 199: 161-167.

2.Zairi A, Nouir S, N MH, Bennani M, Bergaoui I, Mtiraoui A, et al. Antioxidant, antimicrobial and the phenolic content of infusion, decoction and methanolic extracts of thyme and rosmarinus species. Curr Pharm Biotech. 2018; 19(7): 590-599.

3. Saeidnia S, Gohari AR, Manayi A. Reverse pharmacognosy and reverse pharmacology; two closely related approaches for drug discovery development. Curr Pharm Biotech. 2016; 17(11): 1016-1022.

4.Zarshenas MM, Zargaran A. A review on the Avicennass contribution to the field of cardiology. Int J Cardiol. 2015; 182: 237-241.

5. Shah SMA, Akram M, Riaz M, Munir N, Rasool G. Cardioprotective potential of plant-derived molecules: a scientific and medicinal approach. Dose Resp. 2019; 17(2): 1559325819852243.

6. Nielsen E, Temporiti MEE, Cella R. Improvement of phytochemical production by plant cells and organ culture and by genetic engineering. Plant Cell Rep. 2019; 38(10): 1199-1215.

7. Grof CPL. Cannabis, from plant to pill. Br J Clin Pharmacol. 2018; 84(11): 2463-2467.

8. Heydari M, Hashempur MH, Zargaran A. Medicinal aspects of opium as described in Avicenna's Canon of Medicine. Acta Med Hist Adriat. 2013; 11(1): 101-112.

9. Trang T, Al-Hasani R, Salvemini D, Salter MW, Gutstein H, Cahill CM. Pain and poppies: the good, the bad, and the ugly of opioid analgesics. J Neurosci. 2015; 35(41): 13879-13888.

10. Evans CJ. Secrets of the opium poppy revealed. Neuropharmacology. 2004; 47 Suppl 1: 293-299.

11. Meijerink WJ, Molina PE, Abumrad NN. Mammalian opiate alkaloid synthesis: lessons derived from plant biochemistry. Shock. 1999; 12(3): $165-173$.

12. Brand EJ, Zhao Z. Cannabis in Chinese medicine: are some traditional indications referenced in ancient literature related to cannabinoids? Front Pharmacol. 2017; 8: 108.

13. Kaur R, Ambwani SR, Singh S. Endocannabinoid system: a multi-facet therapeutic target. Curr Clin Pharmacol. 2016; 11(2): 110-117.

14. Fraguas-Sanchez AI, Torres-Suarez AI. Medical use of cannabinoids. Drugs. 2018; 78(16): 1665-1703.

15. Konduracka E. A link between environmental pollution and civilization disorders: a mini review. Rev Environ Health. 2019; 34(3): 227-233.

16. Goralczyk K, Majcher A. Are the civilization diseases the result of organohalogen environmental pollution? Acta Bioch Pol. 2019; 66(2): $123-127$.

17. Steinhoff B. Review: Quality of herbal medicinal products: State of the art of purity assessment. Phytomedicine. 2019; 60: 153003.

18. Kumar N, Kulsoom M, Shukla V, Kumar D, Priyanka, Kumar S, et al. Profiling of heavy metal and pesticide residues in medicinal plants. Environ Sci Pollut Res Int. 2018; 25(29): 29505-29510.

19. Orru H, Ebi KL, Forsberg B. The interplay of climate change and air pollution on health. Curr Environ Health Rep. 2017; 4(4): 504-513.

20.Stanojkovic-Sebic A, Maksimovic J, Dinic Z, Postic D, Ilicic R, Stanojkovic A. Microelements and heavy metals content in frequently utilized medicinal plants collected from the power plant area. Nat Prod Comm. 2017; 12(2): 185-188.

21. Glavac NK, Djogo S, Razic S, Kreft S, Veber M. Accumulation of heavy metals from soil in medicinal plants. Arh Hig Rada Toksikol. 2017; 68(3): 236-244.

22. Kohzadi S, Shahmoradi B, Ghaderi E, Loqmani H, Maleki A. Concentration, source, and potential human health risk of heavy metals in the commonly consumed medicinal plants. Biol Trace Elem Res. 2019; 187(1): 41-50. 
23. Ashiq S, Hussain M, Ahmad B. Natural occurrence of mycotoxins in medicinal plants: a review. Fungal Genet Biol. 2014; 66: 1-10.

24. Kabak B, Dobson AD. Mycotoxins in spices and herbs-An update. Crit Rev Food Sci Nutr. 2017; 57(1): 18-34.

25. Aghababaei R, Javadi I, Nili-Ahmadabadi A, Parsafar S, Ahmadimoghaddam D. Occurrence of bacterial and toxic metals contamination in illegal opioid-like drugs in Iran: a significant health challenge in drug abusers. Daru. 2018; 26(1): 77-83.

26. Lawniczek-Walczyk A, Golofit-Szymczak M, Cyprowski M, Stobnicka A, Gorny RL. Monitoring of bacterial pathogens at workplaces in power plant using biochemical and molecular methods. Int Arch Occup Environ Health. 2017; 90(3): 285-295.

27. Saikia J, Khare P, Saikia P, Saikia BK. Polycyclic aromatic hydrocarbons (PAHs) around tea processing industries using high-sulfur coals. Environ Geochem Health. 2017; 39(5): 1101-1116.

28. Pandey A, Belwal T, Tamta S, Bhatt ID, Rawal RS. Phenolic compounds, antioxidant capacity and antimutagenic activity in different growth stages of in vitro raised plants of Origanum vulgare L. Mol Biol Rep. 2019; 46(2): 2231-2241.

29. Roeder E, Wiedenfeld H, Edgar JA. Pyrrolizidine alkaloids in medicinal plants from North America. Pharmazie. 2015; 70(6): 357-367.

30. Chen L, Mulder PPJ, Peijnenburg A, Rietjens I. Risk assessment of intake of pyrrolizidine alkaloids from herbal teas and medicines following realistic exposure scenarios. Food Chem Toxicol. 2019; 130: 142-153.

31.Zaami S, Di Luca A, Di Luca NM, Montanari Vergallo G. Medical use of cannabis: Italian and European legislation. Eur Rev Med Pharmacol Sci. 2018; 22(4): 1161-1167.

32. Parmar JR, Forrest BD, Freeman RA. Medical marijuana patient counseling points for health care professionals based on trends in the medical uses, efficacy, and adverse effects of cannabis-based pharmaceutical drugs. Res Social Adm Pharm. 2016; 12(4): 638-654.

33. Thompson GR, Tuscano JM, Dennis M, Singapuri A, Libertini S, Gaudino R, et al. A microbiome assessment of medical marijuana. Clin Microbiol Infect. 2017; 23(4): 269-270.

34. Booth JK, Page JE, Bohlmann J. Terpene synthases from Cannabis sativa. PloS One. 2017; 12(3): e0173911.

35. Cromey MG, Drakulic J, Beal EJ, Waghorn IAG, Perry JN, Clover GRG. Susceptibility of garden trees and shrubs to Armillaria root rot. Plant Dis. 2019: Pdis06191147re.

36. Gonzalez R, Butkovic A, Elena SF. Role of host genetic diversity for susceptibility-to-infection in the evolution of virulence of a plant virus. Vir Evol. 2019; 5(2): vez024.

37. Redondo MA, Stenlid J, Oliva J. Genetic variation explains changes in susceptibility in a naive host against an invasive forest pathogen: the case of alder and the Phytophthora alni complex. Phytopathology. 2020. doi: 10.1094/PHYTO-07-19-0272-R

38. Alvarez A, Gamella JF, Parra I. Cannabis cultivation in Spain: A profile of plantations, growers and production systems. Int J Drug Pol. 2016; 37: $70-81$.

39. Gilbert AN, DiVerdi JA. Consumer perceptions of strain differences in Cannabis aroma. PloS One. 2018; 13(2): e0192247.
40.Lenton S, Frank VA, Barratt MJ, Potter GR, Decorte T. Growing practices and the use of potentially harmful chemical additives among a sample of small-scale cannabis growers in three countries. Drug Alcohol Depend. 2018; 192: 250-256.

41. Hu H, Wang L, Zhou Q, Huang X. Combined effects of simulated acid rain and lanthanum chloride on chloroplast structure and functional elements in rice. Environ Sci Poll Res Int. 2016; 23(9): 8902-8916.

42. Takamatsu T, Watanabe M, Koshikawa MK, Murata T, Yamamura S, Hayashi S. Pollution of montane soil with $\mathrm{Cu}, \mathrm{Zn}, \mathrm{As}, \mathrm{Sb}, \mathrm{Pb}$, and nitrate in Kanto, Japan. Sci Total Environ. 2010; 408(8): 1932-1942.

43. Joshi SR. Airborne radioactive materials and plants: a review. Sci Total Environ. 1982; 24(2): 101-117.

44.Zuin VG, Vilegas JH. Pesticide residues in medicinal plants and phytomedicines. Phytother Res. 2000; 14(2): 73-88.

45. Szpyrka E, Slowik-Borowiec M. Consumer health risk to pesticide residues in Salvia officinalis L. and its infusions. J Environ Sci Health Part B. 2019; 54(1): 14-19.

46. Ahmed MT, Loutfy N, Yousef Y. Contamination of medicinal herbs with organophosphorus insecticides. Bull Environ Contam Toxicol. 2001; 66(4): 421-426.

47. Al-Waili N, Salom K, Al-Ghamdi A, Ansari MJ. Antibiotic, pesticide, and microbial contaminants of honey: human health hazards. Sci World J. 2012; 2012: 930849.

48. Albert H, Busch J, Klier B, Klotzel M, Kuhn M, Steinhoff B. The occurrence of bromide in herbal drugs: is there a need for a Ph. Eur. limit? Pharmeur Bio Sci Notes. 2013; 2013: 40-63.

49. Shrestha S, Kamel F, Umbach DM, Freeman LEB, Koutros S, Alavanja M, et al. High pesticide exposure events and olfactory impairment among U.S. farmers. Environ Health Perspect. 2019; 127(1): 17005.

50. Palhares RM, Goncalves Drummond M, Dos Santos Alves Figueiredo Brasil B, Pereira Cosenza G, das Gracas Lins Brandao M, Oliveira G. Medicinal plants recommended by the world health organization: DNA barcode identification associated with chemical analyses guarantees their quality. PloS One. 2015; 10(5): e0127866.

51.van Breemen RB, Fong HH, Farnsworth NR. Ensuring the safety of botanical dietary supplements. Am J Clin Nutr. 2008; 87(2): 509s-513s.

52. Malone M, Tsai G. The evidence for herbal and botanical remedies, Part 1. J Family Prac. 2018; 67(1): 10-16.

53. Malone M, Tsai G. The evidence for herbal and botanical remedies, Part 2. J Family Prac. 2018; 67(1): E1-E9.

54. Coutinho Moraes DF, Still DW, Lum MR, Hirsch AM. DNA-based authentication of botanicals and plant-derived dietary supplements: where have we been and where are we going? Planta Med. 2015; 81(9): 687-695.

55. WHO. Quality control methods for medicinal plant materials. Geneva, Switzerland: WHO Press; 2011. p. 1-173.

56. Pielesz A. Vibrational spectroscopy and electrophoresis as a "golden means" in monitoring of polysaccharides in medical plant and gels. Spectrochim Acta A Mol Biomol Spectrosc. 2012; 93: 63-69. 